\title{
Święto Niepodległości 11 listopada i inne święta narodowe w działalności propagandowej i edukacyjnej rządu RP na obczyźnie (lata czterdzieste i pięćdziesiąte XX w.)
}

\begin{abstract}
Abstrakt: Artykuł traktuje o obchodach uroczystości świąt narodowych 3 Maja, 15 sierpnia i 11 listopada w warunkach polskiej Drugiej Wielkiej Emigracji. Chronologicznie uwzględniłem lata 1939-1956, od powołania do życia rządu RP we Francji, po wydarzenia w Polsce, które rozbudziły nadzieje Polaków na obczyźnie na demokratyzację kraju. W rozważaniach zwróciłem uwagę przede wszystkim na działalność rządu RP, z jednoczesnym odwołaniem się do niektórych inicjatyw prezydenta oraz partii, stronnictw politycznych i Polskich Sił Zbrojnych na Zachodzie.
\end{abstract}

Słow a kluc z ow e: edukacja, emigracja, Narodowe Święto Niepodległości, Polskie Siły Zbrojne na Zachodzie, oświata, patriotyzm, prezydent, rząd RP, Święto Wojska Polskiego, 3 Maja.

Abstract: The article deals with the celebration of national days of 3 May, 15 August, and 11 November in the conditions of the second Polish "Great Emigration". The chronological scope of the study covers the years from 1939 to 1956, i.e. from the establishment of the Polish government in France to the events in Poland that awakened hopes of Poles abroad of democratisation of the country. I focus primarily on actions of the Polish government with occasional references to some of the initiatives of the president as well as various associations, political parties and the Polish Armed Forces in the West.

Keyw ords: education, emigration, National Independence Day, Polish Armed Forces in the West, educational system, patriotism, state president, Polish government, Polish Army Day, 3 May. 
W dwudziestoleciu międzywojennym Polacy obchodzili trzy święta w randze uroczystości ogólnopolskich. Były również podejmowane próby dodatkowego uhonorowania w randze uroczystości ogólnopolskich imienin Józefa Piłsudskiego jako jednego z najważniejszych świąt.

Pierwsze, które należy uznać za najważniejsze i najdłużej obecne w przestrzeni publicznej, to 3 Maja, czyli rocznica uchwalenia Konstytucji z 1791 r. w polskiej tradycji połączone ze świętem kościelnym Najświętszej Marii Panny Królowej Polski. Władze II Rzeczypospolitej ustanowiły to święto w 1919 r. Był to dzień wolny od pracy. Po raz ostatni obchodzono je już w sowietyzowanej Polsce w $1946 \mathrm{r}$. Nie bez powodu. 3 V $1946 \mathrm{r}$. w niektórych polskich miastach (np. w Krakowie) doszło do protestów i manifestacji, brutalnie stłumionych przez milicję ${ }^{1}$ Komuniści w zamian natomiast wzmocnili obchody 1 maja w Święto Pracy. Nadając im dużą rangę z wykorzystaniem teatralizacji uroczystości. Jednocześnie zadbali o to, żeby po zakończeniu pierwszomajowych obchodów wystrój polskich miast i wsi, w tym flagi, transparenty, plakaty itd., był natychmiast usuwany noca z przestrzeni publicznej. Ów pośpiech odnosił się do zbliżajaccej się kolejnej rocznicy 3 Maja. Rocznicy, która nie była już dniem świątecznym. Tylko raz i tylko w jednym mieście, w historii PRL, dało się zauważyć odstępstwo od tej praktyki, w Częstochowie w 1966 r. Celowo pozostawiono wówczas czerwone szturmówki, flagi, plakaty, portrety komunistycznych dygnitarzy, transparenty i ulotki, aby uzmysłowić Polakom przybyłym pod Jasną Górę na uroczystości milenium chrztu Polski, że Częstochowa jest miastem robotników i chłopów, przywiązanych do Święta Pracy, nie zaś sanktuarium maryjnym. Prymas Polski kard. Stefan Wyszyński, który przyjechał do Częstochowy na uroczystości tysiąclecia chrztu Polski, w trakcie podróży przez miasto skonstatował wówczas: ,jak tu czerwono"2.

Drugie, które zyskało rangę święta państwowego, to rocznica odzyskania niepodległości w 1918 r. Narodowe Święto Niepodległości zostało ustanowione dopiero w 1937 r., chociaż pierwsze próby uhonorowania 11 listopada gen. Kazimierz Sosnkowski podjał w 1919 r. Niestety inicjatywa generała, po burzliwej dyskusji, nie zyskała aprobaty Rady Ministrów ${ }^{3}$. Jako dzień świąteczny zostało zniesione decyzja Krajowej Rady Narodowej (KRN) w 1945 r. Władze komunistycznej Polski w zamian ustanowiły w dniu 22 lipca Święto Manifestu Polskiego Komitetu Wyzwolenia Narodowego. Jednocześnie do publicznej wiadomości podały, że była to rocznica ogłoszenia dokumentu w pierwszym wyzwolonym polskim mieście - Chełmie Lubelskim. Argumentacja okazała się w całości bałamutna. Po pierwsze, za zgodą Józefa Stalina

${ }^{1}$ W. Mazowiecki, Pierwsze starcie. Wydarzenia 3 maja 1946, Warszawa 1998.

${ }^{2}$ T. Wolsza, Wokót milenium 1966 r., „Wiadomości Historyczne” 2002, nr 4, s. 195-202.

${ }^{3}$ P. Podhorodecki, A. Turza, Pierwszy projekt ustanowienia dnia 11 listopada Narodowym Świętem Niepodległości, „Przegląd Historyczno-Wojskowy” 2018, nr 1-2, s. 394. Por. też: B. Wachowska, Od 11 listopada do 11 listopada czyli spory o symboliczne święto niepodlegtości Polski, „Acta Universitatis Lodziensis. Folia Historica” 1995, nr 54. 
manifest został upubliczniony kilka dni wcześniej, 20 VII 1944 r. w Moskwie. Po drugie, Chełm Lubelski nie był bynajmniej pierwszym wyzwolonym miastem polskim. Kilka miesięcy wcześniej, bowiem już w styczniu 1944 r. Armia Czerwona wkroczyła do miasteczka kresowego Sarny.

W końcu trzecie to Święto Wojska Polskiego, uroczyście obchodzone 15 sierpnia w rocznicę wspaniałego zwycięstwa wojsk polskich nad bolszewikami pod Warszawą w 1920 r. Połączone ze świętem kościelnym Wniebowzięcia Najświętszej Marii Panny. Po raz pierwszy było obchodzone w $1923 \mathrm{r}$. W powojennej Polsce zostało zniesione w 1947 r. W zamian w 1950 r. komuniści postanowili uhonorować uczestników bitwy pod Lenino 12-13 X 1943 r. Dzień Wojska Polskiego upamiętniający bitwę pod Lenino był mocno na wyrost. Przymuszeni przez Sowietów do walki, z góry skazanej zresztą na porażkę, polscy żołnierze w liczbie 776 dostali się do niewoli lub określono ich jako zaginionych (w tym gronie byli i ci, którzy dobrowolnie przeszli na stronę niemiecka, najzwyczajniej zdezerterowali). W 1943 r. szeroko zajmowała się tym tzw. prasa gadzinowa wydawana przez Niemców w języku polskim oraz działajacca nieco później z identycznych pobudek rozgłośnia Wanda, zaadresowana do żołnierzy 2 Korpusu gen. Władysława Andersa ${ }^{4}$.

$$
* * *
$$

W kręgach polskiej emigracji, począwszy od 1939 r., pojawił się pomysł, zresztą zrealizowany, aczkolwiek stopniowo, powołania do życia polskiego państwa na obczyźnie. Sprawa dotyczyła nie tylko odtworzenia władz RP, przede wszystkim wykonawczych (prezydent i rząd) oraz namiastki ustawodawczych (Rady Narodowej). Polska emigracja zwłaszcza po wojnie przyjęła na siebie obowiązki związane z organizacją życia oświatowego, naukowego, kulturalnego i sportowego dla tysięcy rodaków, którzy z różnych powodów pozostali poza krajem. Na barki emigracji spadła również misja informacyjna dotycząca szczegółowego omówienia wydarzeń w krajach za żelazną kurtyna, w tym oczywiście i w Polsce. W końcu pojawił się mocno eksponowany obowiązek podtrzymywania tożsamości narodowej oraz kultywowania polskich rocznic i świąt państwowych, których geneza sięgała dwudziestolecia międzywojennego $^{5}$. Mylił się więc minister i wnikliwy obserwator wydarzeń na emigracji, prof. Adam Pragier, który ongiś skonstatował, że „emigracja polityczna żyje mitem Drugiej Rzeczypospolitej, która już nie istnieje. Zachowuje symbole

${ }^{4}$ T. Wolsza, „To co widziałem przekracza swa grozq najśmielsze fantazje”. Wojenne i powojenne losy Polaków wizytujacych Katyń w 1943 roku, Warszawa 2015, s. 158-160; A. Korol-Chudy, „Czy chcecie, by was nadal wodzono za nos”? Propaganda niemiecka wobec żotnierzy 2. Korpusu Polskiego we Wtoszech. Cele - środki - motywy, w: Za naszq i wasza wolność. Bitwa o Monte Cassino z perspektywy polskiej i wtoskiej, red. C. Salmeri, Katowice 2017, s. $113-137$.

${ }_{5}^{5}$ T. Wolsza, Rzad bez władzy? Uwagi na temat działalności rzqdu RP na obczyźnie w latach 1939-1989. Przeglad i postulaty badawcze, „Dzieje Najnowsze” 2010, nr 4, s. 105-113. 
jej nieprzerwanej ciagłości, ale tylko w sensie nieustającego protestu prze-

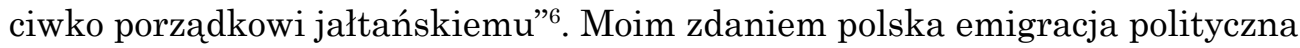
wypełniała znacznie więcej zadań, w tym polityczne, edukacyjne, kulturalne, ekonomiczne, informacyjne, by wymienić w tym miejscu najistotniejsze.

W latach II wojny światowej rocznice świąt narodowych były kultywowane przez władze RP wypełniające swoją misję początkowo we Francji, zaś od 1940 r. na Wyspach Brytyjskich. Z dokumentacji rządu wynika, iż najważniejszym świętem była rocznica uchwalenia Konstytucji 3 maja $1791 \mathrm{r}$. Pozostałe święta straciły na swoim znaczeniu, co nie jest równoznaczne z pomijaniem 15 sierpnia oraz 11 listopada w kalendarzach ministrów rządu RP oraz premiera gen. Władysława Sikorskiego i prezydenta Władysława Raczkiewicza czy też ich następców. Aczkolwiek w warunkach wojny uroczystości, o których wspomniałem, organizowano w skromniejszym zakresie. Niekiedy też towarzyszyły im sytuacje kryzysowe o czytelnym zabarwieniu politycznym. Najbardziej spektakularna wydaje się w tym wypadku decyzja rządu RP z 3 XI 1942 r. Na wniosek premiera Rada Ministrów postanowiła, że „w czasie nowej wojny o niepodległość dzień 11 listopada jako dzień klęski Niemiec w poprzedniej wojnie i oswobodzenia się stolicy Polski obchodzony będzie wyłącznie przez nabożeństwa dla uczczenia wysiłków i ofiar Narodu, będąc poza tym dniem normalnego urzędowania". Czytelna inicjatywa gen. Władysława Sikorskiego odnosiła się przede wszystkim do charakteru święta. Wszak, zgodnie z ustawa z 23 IV 1937 r., 11 listopada, jako rocznica odzyskania niepodległości, był od początku związany z postacią Józefa Piłsudskiego, „zwycięskiego Wodza Narodu w walkach o wolność Ojczyzny”. Generał Władysław Sikorski zakwestionował również artykuł pomieszczony w konspiracyjnym „Biuletynie Informacyjnym” z 8 XI 1940 r., w którym znalazł się fragment poświęcony „geniuszowi intuicji politycznej Józefa Piłsudskiego”. Dowodził, że w publikacji zabrakło choćby jednego słowa entuzjazmu dla rządu RP oraz Naczelnego Wodza ${ }^{8}$. W ślad za tym władze wojskowe rozpoczęły planową akcję dyskredytowania postaci Marszałka przy każdej okazji. Na ten aspekt wydarzenia wskazywał m.in. gen. Kazimierz Sosnkowski, który zaprotestował z powodu polityki oświatowej oczerniającej twórcę Legionów w Polskich Siłach Zbrojnych (PSZ) na Zachodzie9 ${ }^{9}$ W wojsku zakazano organizacji

\footnotetext{
${ }^{6}$ A. Pragier, Puszka Pandory, Londyn 1969, s. 292.

${ }^{7}$ Protokoty posiedzeń Rady Ministrów Rzeczypospolitej Polskiej, t. V: wrzesień 1942 - lipiec 1943, red. nauk. M. Zgórniak, oprac. W. Rojek, współpr. A. Suchcitz, Kraków 2001, s. 53-54.

${ }^{8}$ I. Wojewódzki, Kazimierz Sosnkowski podczas II wojny światowej. Ksiażę niezłomny czy Hamlet $w$ mundurze?, Warszawa 2009, s. 169. Konsternację w kręgach emigracyjnych wywołał również artykuł z pisma Komendy Głównej Związku Walki Zbrojnej „Insurekcja”, w którym płk Jan Rzepecki podjął się próby gloryfikacji postaci Marszałka. Szerzej zob. M. Dymarski, Stosunki wewnętrzne wśród polskiego wychodźstwa politycznego i wojskowego we Francji i w Wielkiej Brytanii 1939-1945, Wrocław 1999, s. 136.
}

${ }^{9}$ I. Wojewódzki, op. cit., s. 169. 
nabożeństw za duszę Piłsudskiego. Tę inicjatywę forsował m.in. minister Marian Seyda, czołowy działacz Stronnictwa Narodowego ${ }^{10}$. Konkludując, jeśli chodzi o sprawy dotyczące aspektów politycznych oraz odwoływania się do wydarzeń z przeszłości związanych z odbudową niepodległości po 123 latach niewoli, to rząd gen. Sikorskiego wykorzystał tę nadzwyczajną sytuację do rozliczenia z sanacją oraz mitem marszałka Józefa Piłsudskiego. Symbolem owego rozliczenia były niewątpliwie obozy internowania (stacje zborne dla oficerów) zlokalizowane we Francji w Cerizay i na Wyspach Brytyjskich, na tzw. Wyspie Węży w Bute, przeznaczone dla oficerów Wojska Polskiego, których nowe władze identyfikowały z przedwojennym obozem Piłsudskiego i jego spadkobiercami ${ }^{11}$. Przez obóz w Rothesay przeszło ok. 20 generałów ${ }^{12}$. Niektórzy z nich zadeklarowali chęć walki nawet w mundurach szeregowców.

Pierwszy 3 Maja na obczyźnie władze RP spędziły wśród żołnierzy 1 Dywizji Piechoty. Po uroczystej mszy polowej, która celebrował ks. prałat Zygmunt Kaczyński, odbyły się defilada oraz obiad żołnierski. Po obiedzie żołnierze odśpiewali szereg pieśni wojskowych. Uroczystość uświetniła swoją obecnościa kilkuosobowa delegacja parlamentu brytyjskiego z Victorem Cazaletem oraz ambasadorem Howardem W. Kennardem na czele. Do Colombey-les-Belles przybyła również generalicja francuska $\mathrm{z}$ ambasadorem Leonem Noëlem ${ }^{13}$. Najważniejszym wydarzeniem z punktu widzenia formującego się wówczas Wojska Polskiego we Francji było wszakże podniesienie bandery polskiej na ORP „Garland”, który w latach 1940-1946 pozostawał w służbie Polskiej Marynarki Wojennej. Dowództwo okrętu obją kmdr ppor. Antoni Doroszkowski. Ponadto prezydent RP mianował na wyższy stopień wojskowy kilku wysokich oficerów: do stopnia generała dywizji Mariana Kukiela oraz Izydora Modelskiego, natomiast Rudolfa Niemirę, Bronisława Ducha, Stanisława Kopańskiego, Stefana Grota-Roweckiego i Tadeusza Bora-Komorowskiego do stopni generałów brygady. Warto również zapoznać się z uroczystościami, jakie przygotowali z okazji święta państwowego żołnierze Brygady Karpackiej na Bliskim Wschodzie. Jej dowódca, gen. Stanisław Kopański wspominał: „3 maja obchodziliśmy pierwszy raz święto narodowe na obczyźnie. Uroczyście podnieśliśmy na wysokim maszcie flagę narodowa w asyście kompanii honorowej. Daleko przez pustynię rozlegała się w tym dniu «Rota» śpiewana przez

${ }^{10}$ K. Kaczmarski, O Wielka Polskę na wojennym wychodźstwie. Stronnictwo Narodowe wobec rzadu gen. Władystawa Sikorskiego (1939-1943), Rzeszów 2013, s. 193.

${ }_{11}$ M. Dymarski, Polskie obozy odosobnienia we Francji $i w$ Wielkiej Brytanii $w$ latach 1939-1942, „Dzieje Najnowsze” 1997, nr 3, s. 113-127. Por. też: J. Zuziak, Obozy izolacyjne Rothesay i Tignabruaich. Z historii Polskich Sit Zbrojnych na Zachodzie, „Mars” 1995, nr 3.

12 M. Dymarski, Polskie obozy odosobnienia..., s. 123.

${ }^{13}$ Dziennik czynności Naczelnego Wodza gen. Wtadystawa Sikorskiego, t. I: 30 VIII 1939 31 VII 1940, wstęp i red. nauk. J. Rabiński, oprac. dokumentów J. Rabiński, E. Rzeczkowska, J. Kowalska, Lublin 2016, s. 611; Dzienniki czynności Prezydenta RP Wtadysława Raczkiewicza 1939-1947, t. I: 1939-1942, oprac. J. Piotrowski, Wrocław 2004, s. 151. 
pierwszych kilkuset żołnierzy Brygady"14. W 1941 r. centralne uroczystości 150. rocznicy uchwalenia Konstytucji 3 maja były zlokalizowane w Londynie. Nabożeństwo celebrował bp Józef Gawlina. W ambasadzie polskiej odbyło się śniadanie, na które prezydent RP Władysław Raczkiewicz zaprosił króla Jerzego VI. Ważnym wydarzeniem była okolicznościowa akademia, podczas której wykład o znaczeniu Konstytucji 3 maja wygłosił prof. Stanisław Stroński. Ponadto zaproszeni goście mogli zapoznać się z krótkometrażowym filmem dokumentalnym w dwóch wersjach językowych na temat polskiej emigracji na Wyspach Brytyjskich (pt. Orzet polski nad Tamiza). W końcu wyjątkowo celne i propolskie przemówienie na falach BBC wygłosił Winston Churchill ${ }^{15}$. Brytyjski premier podkreślił:

\begin{abstract}
Wasi sąsiedzi uznali, że uchwalenie konstytucji 3 maja stanowi początek odrodzenia Polski i pospieszyli zakończyć rozbiory waszego kraju, zanim naród polski zdoła skonsolidować państwo na nowych zasadach. Podobnie było w 1939 r. Niemcy zaniepokoili się postępami narodu polskiego w urządzeniu jego własnego domu. Przejrzeli oni, że ich agresywne zamiary zniweczone zostaną wzrostem potężnego i niepodległego państwa polskiego ${ }^{16}$.
\end{abstract}

Zygmunt Nagórski, wysoki urzędnik Najwyższej Izby Kontroli, zanotował, że „rocznica 3-go maja dała Brytyjczykom okazję do bardzo ostentacyjnego manifestowania swego stanowiska wobec Polski i swych sympatii dla Polaków"17. Kresowiak z Tarnopola Czesław Blicharski, którego Sowieci uwolnili z łagru, podzielił się z czytelnikami swoimi wrażeniami z pierwszych świąt narodowych na wolności. Uczestniczył $\mathrm{w}$ akademii z okazji 11 listopada. „Dziwna to była akademia, tak różna od nadętych szkolnych uroczystości, które zapamiętaliśmy. Od czasu do czasu słychać było szloch kobiet. Przemawiał generał Anders. Wysoki, szczupły, schorowany, opierajacy się na lasce. Na widownię składały się kobiety, [...] ubrane w to, co zdołały zachować z kazachstańskiej "wyprzedaży», trochę "leśnych dziadków», kilkunastu oficerów ze sztabu, pluton łączności oraz młodzież ze szkoły podchorążych" 18 . W oddalonym od Londynu obozie w Latrun w Palestynie polscy żołnierze uczestniczyli w nabożeństwie i defiladzie. Ponadto wysłuchali „pięknego odczytu generała [Kordiana] Zamorskiego i redaktora [Jana] Walewskiego" 19 .

W 1943 r. uroczystości 3 Maja odbyły się w wyjątkowo trudnym dla Polski okresie, tuż po nagłośnieniu przez Niemców, na niespotykaną zresztą

${ }_{14}$ S. Kopański, Wspomnienia wojenne 1939-1946, Londyn [b.d.w.], s. 108.

${ }^{15}$ Dzienniki czynności Prezydenta RP..., t. I, s. 361.

${ }^{16}$ Cyt. za: S. Mękarski, Zapiski z Rothesay 1940-1942, oprac. A. Adamczyk, Londyn-Piotrków Trybunalski 2003, s. 248.

17 Z. Nagórski, Wojna w Londynie. Wspomnienia 1939-1945, Paryż 1966, s. 84.

18 C. Blicharski, Tarnopolanina żywot niepokorny, Warszawa 2013, s. 216.

19 F.S. Składkowski, Nie ostatnie słowo oskarżonego. Wspomnienia i artykuty, wstęp i oprac. A. Adamczyk, Warszawa 2003, s. 431. 
skalę, informacji o odkryciu grobów katyńskich i wskazaniu Sowietów jako sprawców ${ }^{20}$. Pod koniec kwietnia na Uniwersytecie w Londynie rozpoczą się okolicznościowy cykl wykładów na temat Polski. Ambasador RP w Londynie Edward Raczyński wygłosił m.in. referat pt. Tradycje uniwersyteckie $w$ Polsce. Polski dyplomata oceniając wszystkie wydarzenia związane ze świętem, zauważył, iż władze RP zastosowały wówczas ideę „im więcej nas skubia i atakuja, tym bardziej występujemy na zewnątrz absorbując soba przyjaciół i obojętnych, drażniąc niechętnych i wrogich" ${ }^{21}$. Była to czytelna aluzja do wyjątkowo już niechętnej polityki Wielkiej Brytanii wobec rządu RP i spraw polskich, a zarazem do sympatii, jaka Anglicy obdarzali Zwiąek Sowiecki od czerwca 1941 r. Ambasador zauważył jednocześnie, iż przejaw tego stanowiła np. ranga polityków uczestniczących w uroczystościach. W święto Armii Czerwonej na wielkiej akademii w Albert Hall przemawiał minister Anthony Eden. Z kolei w rocznicę Konstytucji 3 maja władze desygnowały na polskie uroczystości członka gabinetu wojennego Johna Andersona „baranka zaplatanego rogami w ciernie”22. Wydarzeniem kluczowym było jednak przemówienie radiowe prezydenta zaadresowane do Polaków w kraju, transmitowane przez sekcję polską rozgłośni BBC. Władysław Raczkiewicz $\mathrm{w}$ wypowiedzi nawiązał do powstania w getcie warszawskim oraz do zbrodni katyńskiej: „Zbrodnia i barbarzyństwo zapanowały nad ziemia polską”. Całe przemówienie, pt. Silna $i$ sprawiedliwa Polska jest jedynym celem wszystkich Polaków, opublikował „Dziennik Polski”. Gros uroczystości lokalnych było rozproszonych po licznych ośrodkach, w których przebywali Polacy. Stanisław Sopicki zanotował w dzienniku: „Obchód 3 Maja wypadł w wielu miastach dość dobrze. Anglicy okazali nam dużo sympatii” ${ }^{23}$.

W 1945 r. uroczystości 3 Maja odbyły się w cieniu ustaleń konferencji Wielkiej Trójki w Jałcie. Nie dawały one powodów do radości i nadziei na przyszłość. Niski urzędnik Foreign Office Richard Law, który zjawił się na obchodach, w okolicznościowym przemówieniu powiedział: „Możemy być dumni, że byliśmy towarzyszami broni w tych czasach. Nigdy nie zapomnimy, że przez Polskę i przez bohaterski opór jej wojsk po raz pierwszy została zatrzymana powódź agresji niemieckiej, która groziła zalewem całej Europie, a nawet całemu światu"24. Była to wypowiedź uprzejma, jednakże nieszczera w świetle polityki władz brytyjskich wobec Polski w latach 1943-1945. Pięć dni później

${ }^{20}$ Skalę działalności propagandowej w sprawie zbrodni katyńskiej najszerzej omówili: E.C. Król, Polska i Polacy w propagandzie narodowego socjalizmu w Niemczech 1919-1945, Warszaw 2006; T. Wolsza, „To co widziałem przekracza swa groza najśmielsze fantazje”..., passim.

${ }^{21}$ W sojuszniczym Londynie. Dziennik ambasadora Edwarda Raczyńskiego 1939-1945, Londyn [b.d.w.], s. 175 .

${ }^{22}$ Ibidem.

${ }^{23}$ S. Sopicki, Dziennik 1943-1944, oprac. M. Dymarski, „Przegląd Polonijny” 1998, z. 2, s. 40.

${ }^{24}$ Z. Nagórski, op. cit., s. 330. 
cały Londyn świętował zakończenie wojny. Natomiast Polacy w „polskim Londynie" byli świadomi zwycięskiej wojny i niestety przegranego pokoju.

Jeśli chodzi o obchody związane ze Świętem Żołnierza, to po klęsce Francji doszły one do skutku już na Wyspach Brytyjskich. Jak można łatwo się domyślić, uroczystości w „polskim Londynie” nie były obchodzone z dużym nakładem sił i środków. 15 VIII 1940 r. odbyła się uroczysta msza z udziałem prezydenta, która celebrował bp Józef Gawlina. Z kolei premier gen. Władysław Sikorski dodatkowo uczestniczył jeszcze w kilku innych wydarzeniach. Wyjechał do szkockiego miasteczka Biggar, w którego okolicach były zlokalizowane Szkoła Podchorążych Piechoty i Centrum Wyszkolenia Łączności. Następnie dotarł do Broughton, w którym mieścił się obóz 4 Dywizji Piechoty. Święto wykorzystano do przyjęcia przysięgi wojskowej przez rekrutów. Tradycyjnie odbyły się również defilada i wspólny obiad żołnierski ${ }^{25}$.

Dysponujemy także relacją z tej uroczystości Stefana Mękarskiego, który niebawem, z uwagi na poglądy polityczne, został na kilka miesięcy, podobnie jak kilkudziesięciu innych oficerów, zawieszony w służbie wojskowej. Przed przybyciem premiera odbyło się nabożeństwo w kaplicy. Ksiądz stwierdził, że „bitwę pod Warszawą wygrał Piłsudski. W rozkazie dziennym dotyczącym święta również była mowa o Naczelnym Wodzu Piłsudskim w r. 1920". Referent oświatowy w jednostce Marian Ligocki w okolicznościowym odczycie wielokrotnie wymienił nazwisko Piłsudskiego i przy okazji zredukował rolę w wydarzeniach z sierpnia 1920 r. francuskiego gen. Maxime'a Weyganda. Jego zdaniem doradzał on „wycofanie się pod Kraków i w poznańskie i walkę pozycyjna" ${ }^{26}$. Następnie odbyło się spotkanie z premierem i Naczelnym Wodzem w jednej osobie. Towarzyszyli mu gen. Marian Kukiel, prof. Stanisław Kot i kilku członków Rady Narodowej. Premier nie bacząc na rangę święta, zaatakował swoich oponentów politycznych w wojsku. Jego przemówienie było pozbawione motywów niepodległościowych oraz niestety analizy wydarzeń sprzed 22 lat. Generał Sikorski podkreślił, że kilku oficerów, w tej chwili można wysunać hipotezę, że sprawa dotyczyła tych, którzy po 1926 r. pełnili władzę polityczna, wysłał na „małpią wyspę”, czyli do Bute. Dodał przy tym, że mógłby wszystkich zamknać w angielskich obozach koncentracyjnych, ale nie pozwoliła mu na to „duma narodowa”. Mękarski zauważył, że przemówienie było politycznie błędne, niezręczne i szkodliwe. Pamiętnikarz natomiast wyróżnił postawę oficerów wysłanych na wyspę Bute, którzy na dworcu w Broughton odśpiewali demonstracyjnie My, Pierwsza Brygada. Komendant obozów w Biggar i Broughton, gen. Stefan Dembiński „zażenowany słuchał tej demonstracji ze spuszczonymi oczami” ${ }^{27}$. Jednocześnie władze RP zadbały o to, aby nieliczne media, którymi dysponowali

\footnotetext{
${ }^{25}$ Dziennik czynności Naczelnego Wodza..., s. 77.

${ }^{26}$ S. Mękarski, op. cit., s. 44.

${ }^{27}$ Ibidem, s. 45.
} 
Polacy na emigracji, nie eksponowały zanadto postaci Marszałka i jego wkładu w dzieło odbudowy niepodległości Polski. W maju 1940 r., w 5. rocznicę śmierci Józefa Piłsudskiego, redaktor Wacław Zbyszewski z sekcji polskiej BBC już za sam fakt, iż odważył się podnieść problem obecności Marszałka w polityce, został usunięty ze stanowiska. Dodatkowo po interwencji premiera otrzymał rozkaz od Komisji Poborowej stawienia się do wojska, chociaż w świetle kategorii zdrowia „E” był niezdolny do służby ${ }^{28}$. To niejedyne przykłady świadczące o planowej akcji wyeliminowania postaci Józefa Piłsudskiego z dyskursu publicznego, np. w kontekście walki o niepodległość lub jego roli w II Rzeczypospolitej. Można również tu zauważyć, że gen. Sikorski, który jak sądzę - miał kompleks Piłsudskiego, w ogóle nie dopuszczał takiej sytuacji, aby kiedykolwiek wspominać o Marszałku, bez względu na to, czego by sprawa nie dotyczyła. Po katastrofie gibraltarskiej w lipcu 1943 r., w której tragicznie zginą premier RP, ów pomysł nadal realizowali jego przyjaciele i współpracownicy. W dalszym ciąu aktualna była instrukcja Stanisława Strońskiego z 1939 r., w której minister doprecyzował taktykę działania wobec Marszałka:

stwierdziłem, że rząd świadom naczelnej odpowiedzialności Piłsudskiego za całość zdarzeń od maja 1926 r. zachowuje jednak sam i poleca wszystkim spokojne milczenie dokoła jego nazwiska, lecz wszelkie wysławianie uważa za drażniące kraj i wprowadzające zamęt pojęć w państwach sprzymierzonych i przyjaznych, gdzie wszystkim wiadomo, że Piłsudski wprowadził w Polsce rządy osobistej dyktatury oraz wiadomo czym się to skończyło, a więc wysławianie jest dla zagranicy niezrozumiałe i zaciera odcięcie okresu i rządu obecnego od poprzedniego ${ }^{29}$.

Stanisław Mikołajczyk przypomniał ongiśs rozmowę z premierem Wielkiej Brytanii Winstonem Churchillem. W jej trakcie pojawił się w pewnym momencie wątek dotyczący gen. Władysława Sikorskiego. W Instytucie Historycznym im. gen. Sikorskiego w Londynie premier Wielkiej Brytanii oprócz siebie przywołał również postaci Władysława Sikorskiego i Józefa Piłsudskiego jako uczestników walki z Rosja. Potem organizatorzy zwrócili mu uwagę, że popełnił zasadniczy błąd, gdyż Piłsudski był „najzaciętszym wrogiem generała Sikorskiego". Winston Churchill tłumaczył się, że tylko napomknął o Piłsudskim, lecz nawet to wystarczyło do krytyki. Potem

28 J. Piotrowski, „Skandaliczna” audycja w polskojęzycznej rozgłośni BBC 12 maja 1940 r., „Niepodległość” 2007, t. LVII, s. 189-196. Por. również ocenę wydarzenia przygotowaną przez prof. Stanisława Strońskiego: „Rząd ani jednym słowem nie dotyka ujemnie nazwiska Piłsudskiego, ale nie może widzieć, że wysławianie go jest szkodnictwem wobec zagranicy, gdyż poddaje w wątpliwość naszą dojrzałość polityczna, a zarazem jest drażnieniem i wyzywaniem kraju, który cierpi za to, co się działo oraz wie kto jest za to na pierwszym miejscu odpowiedzialny”. W kraju $i$ na emigracji. Materiaty $z$ londyńskiego archiwum ministra prof. Stanistawa Kota (1939-1943), wybór i oprac. J. Gmitruk, Z. Hemmerling, J. Sałkowski, Warszawa 1989, s. 71.

${ }^{29}$ Ibidem, s. 70-71. 
w rozmowie ze Stanisławem Mikołajczykiem dodał: „być może popełniłem błąd - ale już się stało" 30 .

W 1944 r. Święto Żołnierza zbiegło się z Powstaniem Warszawskim. Wydarzeniu towarzyszył Apel Prezydenta RP, opublikowany w „Dzienniku Żołnierza" 14 VIII 1944 r. Z kolei w 1945 r. kluczowe obchody odbyły się we Włoszech i były związane z żołnierzami 2 Korpusu. Wprowadzenie do uroczystości stanowiło spotkanie kilku generałów, które zaaranżował w Londynie prezydent Władysław Raczkiewicz. Przybyli na nie generałowie: Władysław Anders, Stanisław Maczek, Klemens Rudnicki, Janusz Głuchowski i Stefan Dembiński-Dembina. W świat poszła jednak informacja dotycząca obchodów we Włoszech 15 VIII 1945 r. Z dwóch powodów: obecności marszałka Harolda Alexandra oraz ostatniej wielkiej defilady żołnierzy 2 Korpusu. Dowódca legendarnego oddziału zanotował:

dzień 15 sierpnia był rokrocznie uroczyście obchodzony w wojsku polskim dla upamiętnienia zwycięskiej bitwy pod Warszawą w roku 1920, gdy wojsko czerwone odparto nieomal sprzed wrót Warszawy i rozpoczął się pościg, zakończony zwycięstwem. Polska była wówczas w śmiertelnym niebezpieczeństwie. Wspaniały zryw żołnierza polskiego ocalił wtedy nie tylko Polskę, ale i Europę Środkową od bolszewizmu. Rocznicę tę obchodziliśmy w Anconie i Loreto ${ }^{31}$.

Podczas defilady dywizji pancernej, jak podkreślił gen. Władysław Anders, „doświadczony w bojach żołnierz pokazał się z najlepszej strony, wykazując zupełne opanowanie sprzętu w trudnej dyscyplinie marszowej wielkiej jednostki pancernej" ${ }^{32}$. Po wizytacji marszałek pogratulował wspaniałych żołnierzy polskiemu generałowi. W specjalnej depeszy zaadresowanej do gen. Władysława Andersa skonstatował m.in.: ,jestem dumy, że byłem związany z Panem Generałem i jego doskonałym wojskiem od początku, jeszcze przed El Alamein, w czasie gdy Pan Generał budował tę wielką maszynę wojenna, która odegrała tak piękną i wybitną rolę w naszych wielkich zwycięstwach" ${ }^{33}$. Dla żołnierzy 2 Korpusu było to wyróżnienie, niestety już ostatnie w ich wielkiej historii. Nie powrócili do Polski i w strony rodzinne. Polski nota bene sowietyzowanej przez Sowietów, strony rodzinne - Kresy Wschodnie, które za przyzwoleniem Anglosasów zostały odebrane Polsce. Tych, którzy pozostali na emigracji, objęto programem Polskiego Korpusu Przysposobienia i Rozmieszczenia. Rozproszeni po świecie rozpoczęli pracę w cywilnych zawodach. Przez jakiś czas oczekiwali na wybuch III wojny światowej.

W latach 1940-1942 premier rządu gen. Władysław Sikorski, z racji pełnionego stanowiska prezesa Rady Ministrów, często zabierał głos na

\footnotetext{
${ }^{30}$ Polski ruch ludowy na emigracji (1944-1954). Dokumenty i materiaty, cz. 1, nota wydawnicza, wprowadzenie, oprac. i wybór R. Turkowski, Kielce 2005, s. 205.

${ }^{31}$ W. Anders, Bez ostatniego rozdziatu. Wspomnienia z lat 1939-1946, Lublin MCMXCII, s. 412.

${ }^{32}$ Ibidem.

${ }^{33}$ Ibidem.
} 
uroczystościach związanych ze świętami państwowymi. Można też tu zauważyć, że rokrocznie 11 listopada miał zawsze zagwarantowany głos decydujący. Była więc to nie lada okazja do dyskredytowania Józefa Piłsudskiego i jego obozu politycznego. Jednocześnie, dla przeciwwagi, doceniał osiagnięcia II Rzeczypospolitej. W 1942 r. w obszernym przemówieniu stwierdził m.in., że w 1918 r. Polska powstała na gruzach Niemiec. Był to ważny wątek, który pozwolił premierowi na konstatację, że „teraz będzie tak samo”. Gros uwagi poświęcił ustrojowi kraju. Docenił równość obywateli wobec prawa, bez względu na różnice wyznaniowe i narodowe. Podkreślił, że sejm zagwarantował wszystkim wolność polityczna, religijną i społeczna. Wysoko ocenił politykę zagraniczna - podyktowaną „polska racją stanu”. Dalej zauważył, że Polacy niezwykle szybko zorganizowali administrację oraz Siły Zbrojne, które od „pierwszego niemal momentu podjęły bój o odwieczne siedziby polskie, by wysiłkiem własnym wyrąbać granice państwa”. Nadmienił też o osiagnięciach gospodarczych i komunikacyjnych. „Podnieśliśmy politycznie i gospodarczo nasze Kresy Wschodnie, zespalając je na powrót mocno z Macierza”. W końcu przystapił do ataku, oczywiście wymierzonego w Józefa Piłsudskiego. Okres rząów obozu Piłsudskiego, zwłaszcza zaś po śmierci Marszałka, określił negatywnie. Sam Marszałek jednak doczekał się krótkiej kurtuazyjnej, pozytywnej wzmianki: „udział Piłsudskiego pierwszego Naczelnika Państwa i Naczelnego Wodza Polskich Sił Zbrojnych w wysiłkach wspomnianego dwudziestolecia jest przemożny”. Dalsza część przemówienia nie pozostawiła już żadnych złudzeń.

Rząd obecny nie uzurpuje sobie prawa, by sądzić dziś jego [Piłsudskiego] dodatnie czy ujemne strony. Zrobi to kiedyś historia. Odcina się on natomiast jak najbardziej stanowczo od błędów niedawnej epoki. Jest nam bowiem zupełnie obca, sprzeczna z podstawowymi interesami Państwa Polskiego polityka zagraniczna ostatnich lat. Wstrętne nam jest wszelkie naśladownictwo wzorów totalistycznych, w polityce wewnętrznej Państwa z tego czasu. [...] Winni następstw tej niepoczytalnej polityki nie mają i mieć nie będą w przyszłej Polsce głosu miarodajnego ${ }^{34}$.

O ile premier pozornie oszczędził Marszałka, o tyle bez cienia wątpliwości poddał totalnej krytyce jego współpracowników i następców. W sumie jednak konstatacja odnosząca się do rządów totalistycznych stanowiła niewątpliwie przemyślaną uwagę pod adresem Józefa Piłsudskiego. Premier ponadto przy innej okazji przeciwstawił znaczeniu Legionów doniosłą rangę wojska, które rząd RP odtworzył po wrześniu 1939 r. we Francji. W 1940 r. w wywiadzie dla „Wiadomości Polskich” powiedział: „Jest nas mało, ale dużo jednocześnie. Żołnierz pierwszorzędny. Żołnierz, który budzi nie tylko szacunek, ale, i podziw u obcych. Jest go trzy razy tyle, ile było w legionach"35.

${ }^{34}$ Cyt. za: S. Stroński, Polityka Rzqdu Polskiego na Uchodźstwie w latach 1939-1942, t. III, oprac. J. Piotrowski, Nowy Sącz 2007, s. 557-558.

${ }^{35}$ Cyt. za: M. Dymarski, Stosunki wewnętrzne..., s. 87. 
Jak sądzę, czytelna była geneza wielkiej niechęci samego Władysława Sikorskiego, jak i jego sympatyków, do Józefa Piłsudskiego. Zaważyły tu przede wszystkim relacje Piłsudskiego i Sikorskiego w latach I wojny światowej, w tym kilka istotnych wydarzeń. Legioniści powszechnie wyśmiewali pułkownika z Naczelnego Komitetu Narodowego, czyli Sikorskiego, który „rządził za biurka i nie wąchał prochu”. Był on nawet niechlubnym bohaterem legionowych przyśpiewek (np. autorstwa Bolesława Wieniawy-Długoszowskiego). Przeciwstawiali mu zaś licytację sprawy polskiej wzwyż, która Komendant realizował skutecznie z legionistami. Dalej zaś wymienić należy genialny plan opracowany przez Piłsudskiego w czasie wojny polsko-bolszewickiej 1920 r. Generał Sikorski był również jednym z dowódców, ale pozostał w cieniu Marszałka. Podobnie nie przebił się do panteonu najwybitniejszych gen. Józef Haller, słynny dowódca Błękitnej Armii. Nawet wymyślony przez narodowców Cud nad Wisłą nie zminimalizował roli i znaczenia Piłsudskiego w tej wojnie. Na rewanż gen. Sikorski czekał 20 lat. Był on jednak przede wszystkim już wymierzony w spadkobierców Marszałka. Premier dyskredytował ich aspiracje do współuczestniczenia we władzach państwowych.

W 1943 r. władze RP nader starannie przygotowywały się do święta odzyskania niepodległości. Wszak była to 25 . rocznica. Niestety wydarzenia z wiosny i lata 1943 r. pokrzyżowały Polakom szyki. Problem zbrodni katyńskiej, nagłośniony przez Niemców na wiosnę, skutkujący zerwaniem przez Związek Sowiecki stosunków dyplomatycznych z rządem RP, oraz śmierć premiera rządu w lipcowej katastrofie gibraltarskiej nie sprzyjały organizacji uroczystości. Główne przemówienie wygłosił nowy prezes Rady Ministrów, Stanisław Mikołajczyk. Bronił Polski przed niesłusznymi i krzywdzącymi zarzutami ze strony anglosaskich sojuszników i Związu Sowieckiego. Dalej obiecywał na przyszłość Polskę demokratyczna, domagał się uwzględnienia naszych terytorialnych żądań w stosunku do Niemiec, nic nie wspomniał ani słówkiem o granicy wschodniej. Zdobył się tylko na uwagę: „Kiedy w sprawie polskiej panuje milczenie lub atakuje się nas niesłusznie, zmuszony jestem przypomnieć naszą walkę" ${ }^{36}$. Z kolei prezydent Władysław Raczkiewicz w przemówieniu wygłoszonym przez radio BBC i zaadresowanym do rodaków w kraju i za granica porównał sytuację z 1943 r. z ta, jaką Polacy wywalczyli w 1918 r. W konkluzji zaś podkreślił, że z „krwawego zmęczenia wojny Polska wyjdzie nie tylko jako państwo okrzepłe i zdążajace do lepszej przyszłości, ale jako państwo pełniej niż kiedykolwiek żyjące w Europie i na świecie" ${ }^{37}$.

Fiaskiem zakończyła się natomiast próba upublicznienia w języku angielskim przez ambasadora Edwarda Raczyńskiego informacji okolicznościowej

\footnotetext{
${ }^{36}$ Z. Nagórski, op. cit., s. 211.

${ }^{37}$ M. Tchórzewska-Hautt, Obchody dnia niepodległości w Polsce w latach 1920-1988, w: Idea niepodlegtości $i$ suwerenności narodowej $w$ działalności Polaków w kraju i na obczyźnie (1918-1998), red. M. Szczerbiński, Gorzów Wlkp. 2000, s. 286.
} 
dotyczącej polskiej rocznicy, podobnie jak to wcześniej uczynili Czesi, oczywiście za zgodą Anglików. Gospodarze stwierdzili, że polskie święto przypada na 3 maja i nie wydali stosownej zgody. Ambasador uznał tę decyzję za „pomniejszą porażkę"s8.

W 1944 r. ważne i słynne przemówienie w rocznicę zwycięskiej Bitwy Warszawskiej wygłosił gen. Władysław Anders:

My, żołnierze 2. Korpusu, jesteśmy Małą Polska. Większość z nas przybyła z Rosji. Później dołączyła do nas Brygada Karpacka z klejnotem sławy Tobruku. Pod Monte Cassino biliśmy się $\mathrm{w}$ najstraszliwszej z bitew świata [...]. Wroga nam propaganda przez radio, prasę, przez płatnych agentów dowodziła, że gen. Anders i jego żołnierze sa faszystami. Czynem zbrojnym odpowiedzieliśmy na to oszczerstwo. Pokazaliśmy światu, że bijemy się z każdym, kto sięga po najświętszą dla nas rzecz Wolność i Niepodległość. [...] Polska jest tam, gdzie bije polskie serce, gdzie jest czyn i walka żołnierska. Bo tylko przez walkę, tylko przez krew, przez drogę ciernistą i trudną my do Ojczyzny dojść możemy. My nie znamy różnicy. Dla nas tak samo cenny jest Śląsk, jak Wilno, Warszawa, Pomorze, Lwów, jak Poznańn ${ }^{39}$.

$$
* * *
$$

Tragiczne losy przywódców Polskiego Państwa Podziemnego porwanych przez NKWD i wywiezionych potajemnie do Moskwy, zakończenie działań wojennych w Europie oraz cofnięcie uznania przez Francję, później zaś przez Anglosasów dla rządu RP pod prezesurą Tomasza Arciszewskiego latem 1945 r., w zasadniczy sposób skomplikowały postawy Polaków w „polskim Londynie". Prezydent i rząd znaleźli się w wyjątkowo trudnej sytuacji. Pewne było jedynie to, iż władze RP nie zaprzestają działalności i będą konsekwentnie wypełniały swoją misję, którą rozpoczęły w 1939 r. we Francji.

Maj 1945 r. nie sprzyjał rozważaniom historycznym i organizacji uroczystości patriotycznych. Sytuacja uległa nieco zmianie cztery miesiące później. 15 VIII 1945 r. odbyła się msza z udziałem prezydenta z okazji Święta Żołnierza, która celebrował ks. prałat Bronisław Michalski. Władysław Raczkiewicz spotkał się również z Naczelnym Wodzem gen. Tadeuszem Borem-Komorowskim, który w maju przyjechał do Londynu prosto z niewoli niemieckiej. Z kolei 11 listopada w uroczystej mszy uczestniczyli prezydent, premier, generalicja oraz przedstawiciele szeregu emigracyjnych organizacji. Jednocześnie „Dziennik Polski i Dziennik Żołnierza”, który w tym okresie pełnił rolę gazety prezentującej stanowisko rządu, opublikował kilka artykułów na temat 25. rocznicy Bitwy Warszawskiej. Anonimowy autor podkreślił duże znaczenie święta w dwudziestoleciu międzywojennym. Wskazał ponadto na szczególny jego charakter:

${ }^{38}$ W sojuszniczym Londynie..., s. 211.

${ }^{39}$ Generał broni Władystaw Anders. Wybór pism i rozkazów, wstęp, wybór i oprac. B. Polak, Warszawa 2009, s. 156-157. 
Wśród rozmaitych rocznic, wśród narodowych świąt, dzień 15 sierpnia był dniem największego zjednoczenia i... największego podziału. Zjednoczenia obok wspomnień, symbolów i tradycji. Podziału na „cywilów” i „żołnierzy”. Cywilna część społeczeństwa, zalegająca szczelnie chodniki [...] wołała każdym swym gestem, każdą wiązanka kwiatów, każdym błyskiem oczu: „Żołnierzu, wierzymy w Ciebie! Dla Ciebie wszystko!” Żołnierz wybijający na jezdni rytm defiladowego kroku, zdawał się odpowiadać: „Wiem! Rozumiem! Spełnię swój obowiązek!"40.

Za istotne z punktu widzenia rozgrywających się wydarzeń w latach wojny i okupacji należy uznać celowe przejście w narracji do zagadnień współczesnych. Nie było więc dziełem przypadku, że pojawiły się w tekście: Narwik, Tobruk, Monte Cassino i Normandia. Szczególną rolę zaś przypisał Armii Krajowej, która stała się ogólnopolska siłą zbrojna, w której każdy bez względu na wiek, płeć i fizyczne możliwości mógł odbyć służbę wojskową. Celnie też zauważył, iż „chociaż mijały jedna za drugimi rocznice Święta Żołnierza bez defilad i kwiatów, bez okrzyków na ulicach, iluminacji i sztandarów - samo święto narastało poczuciem wspólnoty, silniejszej niż kiedykolwiek, wzbogacało się o nowe pragnienia, kształtowało i urealniało wizję przyszłej Polski!" ${ }^{11} \mathrm{~W}$ korespondującym z powyższym tekstem artykule pt. 11 listopada ten sam autor wskazał na osiagnięcia wynikające z uzyskania niepodległości. Szczegółowo opisał drogę do niej wiodąca: powstania w XIX stuleciu, powstania śląskie i wielkopolskie oraz niezaprzeczalny wkład w dzieło odbudowy Niepodległej dywizji syberyjskich w Rosji. W konkluzji podkreślił:

Jedenastego listopada 1918 r. powstała Polska Niepodległa, było to jednak z gruntu inne państwo, niż Rzeczpospolita, którą złożono do grobu po kościuszkowskiej Insurekcji. Było to państwo nie jednej warstwy, nie jednostronnych przywilejów, ale jednolitego narodu. Wielka epoka przemian, której etapami były powstania i rewolucje, zakończyła się przekształceniem państwa stanowego w państwo nowoczesne. I to był najgłębszy sens Dnia Niepodległości ${ }^{42}$.

Zaznaczył też, że tak jak przed laty społeczeństwo z dumą i wzruszeniem patrzyło na nowe życie rozwijające się nad grobami bohaterów, tak i teraz, w 1945 r. nadzieję należy pokładać w narodzie.

W 1946 r. zakres obchodów był rozbudowany i wielowątkowy. „Dziennik Polski i Dziennik Żołnierza” opublikował na pierwszej stronie wieloszpaltowy tekst pt. W 155 rocznice Konstytucji 3 Maja „Rewolucja tagodna”. Artykuł zawierał m.in. opinie polityków brytyjskich na temat ogromnego znaczenia konstytucji: Winstona Churchilla z 1941 r. i Ernesta Bevina z 1944 r. Obaj podkreślili, że konstytucja była w „swoim czasie najbardziej postępowa i demokratyczną i stała się przedmiotem pochwały ówczesnego męża stanu

${ }^{40}$ (m. s), Polska szła ku prawdziwej Demokracji, „Dziennik Polski i Dziennik Żołnierza”, 15 VIII 1945, nr 192.

${ }^{41}$ Ibidem.

${ }^{42}$ (m. św.), 11 listopada, „Dziennik Polski i Dziennik Żołnierza”, 12 XI 1945, nr 268. 
Anglii, Burkego" ${ }^{43}$. Na uroczystości państwowe z okazji rocznicy uchwalenia Konstytucji 3 maja składały się tradycyjnie msza, w której uczestniczyli prezydent oraz premier z całym gabinetem. Polsko-Angielskie Stowarzyszenie Katolickie zorganizowało uroczysty koncert z udziałem wybitnych śpiewaczek: Niny Grudzińskiej i Haliny Zakrzewskiej, chóru Wojska Polskiego oraz tancerek. Warto wyróżnić również to, że w świątecznym numerze „Dziennika Polskiego i Dziennika Żołnierza” redakcja pomieściła artykuł dr. Stefana Mękarskiego, poświęcony polskiej młodzieży na obczyźnie. Można to odczytać jako apel o rozwój oświaty i szkolnictwa. Autor celnie podkreślił, że „nie wolno młodzieży polskiej, która najpiękniejsze swe lata poświęciła - kosztem niepodległości ojczyzny - dla zwycięstwa zachodnich demokracji, pozbawić przyrodniego prawa do wiedzy i nauki”" Można skonstatować, że było to przygotowanie do ważnej akcji pt. „Dar 3-go Maja” pod patronatem prezydenta Władysława Raczkiewicza. Jej cel stanowiło dofinansowanie oświaty dla dzieci polskich na emigracji. Do akcji przyłączyły się emigracyjne organizacje, jak np. Zrzeszenie Profesorów i Docentów Szkół Akademickich, Zrzeszenie Nauczycieli Polaków na Obczyźnie i Światowy Związek Polaków z Zagranicy. Była to czytelna zapowiedź, że pobyt na emigracji przedłuży się i nadzieja spoczywa w młodym pokoleniu Polaków ${ }^{45}$. Inicjatywa edukacyjna „Dar 3-go Maja" natychmiast została powielona w komunistycznej Polsce, z promowaniem innych wartości włącznie. Był to np. tydzień oświaty marksistowskiej pod patronatem Bolesława Bieruta. W kręgach emigracyjnych największy rezonans uzyskały uroczystości w 1951 r., w 160. rocznicę uchwalenia Konstytucji 3 maja. Ujrzały wówczas światło dzienne broszurka prof. Wacława Komarnickiego, pt. Konstytucja 3-go Maja na tle porównawczym oraz odezwa do Polaków przygotowana przez dr. Mieczysława Giergielewicza, prezesa Funduszu Oświaty Polskiej Zagranica ${ }^{46}$.

Nie sposób też w tym miejscu pominąc innego ważnego wątku, który dotyczył losów PSZ, zwłaszcza zaś 2 Korpusu. Los tak zrządził, że tuż przed Świętem Żołnierza w 1946 r. 2 Korpus sposobił się do przyjazdu na Wyspy Brytyjskie w ramach angielskiego planu związanego z Polskim Korpusem Przysposobienia i Rozmieszczenia. Żołnierzy żegnał na ziemi włoskiej gen. Władysław Anders, witał na Wyspach Brytyjskich premier rządu polskiego Tomasz Arciszewski. Sprawa była więc niezwykle ważna. Generał w przemówieniu wygłoszonym w Ankonie nawiązał do nieobecności żołnierzy PSZ na paradzie „V Day” w Londynie 8 V 1946 r.

${ }^{43}$ W 155 rocznice Konstytucji 3 Maja. „Rewolucja tagodna”, „Dziennik Polski i Dziennik Żołnierza", 3 V 1946, nr 104.

${ }^{44}$ St. M. [S. Mękarski], Młodziė̇ na obczyźnie, „Dziennik Polski i Dziennik Żołnierza”, 15 VIII 1946, nr 191.

45 A. Dobroński, Obchody rocznic Konstytucji 3 Maja w „polskim Londynie”, w: Między historiq a prawem, red. P. Leszczyński, R. Nir, M. Szczerbiński, Gorzów Wlkp. 2007, s. 488.

${ }^{46}$ Ibidem, s. 493. 
Nie jest to „V Day” polski, bo Polska jest jeszcze w niewoli. Nie jest to „V Day” świata, bo cała Europa Środkowa ze 127 milionami ludności jest za żelazną kurtyna rządów sowieckich. Stamtąd idzie groźba dla cywilizacji chrześcijańskiej, kultury europejskiej, dla wolności narodów człowieka. Stamtąd idzie najstraszliwsza reakcja i totalitaryzm przeciwko demokracji. Jeżeli nie ma nastapić zagłada świata, wierzymy, że nastapi „V Day” dla wszystkich, prawdziwe bohaterstwo narodów i pokój ludzi dobrej woli ${ }^{47}$.

W kolejnym przemówieniu w Mediolanie 15 VIII 1946 r., zaadresowanym do 4 Wołyńskiej Brygady, przywołał dwa ważne wydarzenia z przeszłości. Odwołał się do wojny polsko-bolszewickiej i Bitwy Warszawskiej. Generał Władysław Anders podkreślił, że polski naród odzyskał wówczas faktycznie wolność i niepodległość. Ponadto biorąc pod uwagę miejsce, w którym przemawiał Mediolan, mógł rozwinąć jeszcze jeden aspekt zagadnienia, dotyczący polskiej drogi do niepodległości. „Blisko 150 lat temu, z tego samego Placu, na którym dziś stoimy, wyruszyły Legiony Dąbrowskiego z napisem na ramieniu «Ludzie wolni są braćmi»" ${ }^{48}$. Premier natomiast swoje przesłanie rozpoczą od wyliczenia zasług polskich żołnierzy: Tobruku, Monte Cassino, Ankony, linii Gotów i Bolonii. Nawiązał do roli Wysp Brytyjskich, które udzieliły gościny władzom RP. Dalej podkreślił, iż z tego samego miejsca startowały polskie dywizjony w bitwie o Anglię, stąd wyruszyły do boju 1 Dywizja Pancerna i Brygada Spadochronowa. Ważną część wypowiedzi Arciszewskiego stanowiły jego losy sięgajace zaborów. Przypomniał, że właśnie z Wysp Brytyjskich od 1898 r. prowadził jako działacz Polskiej Partii Socjalistycznej walkę o uwolnienie Polski. W konkluzji dodał otuchy przyjeżdżającym żołnierzom:

Traktujcie ten pobyt w Wielkiej Brytanii, jako jeden z etapów na drodze do niepodległości Rzeczypospolitej. Wszyscy Polacy znajdujący się na tej wyspie stanowić musimy jedną zwarta, świadomą swych celów gromadę. Każdy z nas jest cząstka tego bogactwa narodowego i siły, jaką reprezentuje wolna społeczność polska, przebywająca czasowo na obczyźnie. Będziemy wspomagać się wzajemnie, dążąc razem do przełamania wszelkich przeszkód na naszej drodze do Polski ${ }^{49}$.

W 1946 r. pojawiła się również okazja do zastanowienia się nad problemem niepodległości Polski. Jest zrozumiałe, że ów temat w szerokim ujęciu stanął na porządku dziennym 11 listopada. Autor w czytelnej formie porównał sytuację Polski w 1918 i 1945 r. Rozpoczął od prezydentów USA. Po stronie plusów zanotował politykę prezydenta Thomasa Woodrowa Wilsona i jego 13 punkt dotyczący powstania niepodległego państwa polskiego z dostępem do morza, zaś po stronie minusów - decyzje Franklina Delano Roosevelta,

${ }^{47}$ Generat broni Wtadystaw Anders..., s. 272.

${ }^{48}$ Ibidem, s. 275.

${ }^{49}$ T. Arciszewski, Do Żotnierzy II Korpusu Wojsk Polskich, „Dziennik Polski i Dziennik Żołnierza", 12 VIII 1946, nr 188. 
który nazywał Polaków „natchnieniem świata” i już niebawem ich zdradził w Teheranie i Jałcie. Idąc dalej tropem porównania wydarzeń z I i II wojny, pojawiła się sprawa władzy z nadania zaborców. Dla lat I wojny światowej były to Tymczasowa Rada Stanu i Rada Regencyjna, dysponujace zdaniem dziennikarza „fikcyjną władza”. Z kolei dla okresu II wojny światowej pojawił się przykład tzw. Tymczasowego Rządu Jedności Narodowej, którego geneza sięgała zgody Józefa Stalina oraz „pseudoparlamentu” KRN. Autor skonstatował, że „w jednym i drugim przypadku mamy do czynienia z kreacja obca przy której narodzinach nie było woli i zgody Narodu Polskiego". Aczkolwiek przy ocenie polityków, którzy z nadania Niemców w latach 1916-1918 i Sowietów w latach 1944-1945 obejmowali władzę, dostrzegł zasadnicze różnice. Ci mianowani przez Niemców to „aktywiści”, przez Sowietów zaś to obecne marionetki, „zwyczajni agenci obcy”50.

Z ustaleń Rafała Habielskiego wynika, że w zakresie obchodów rocznic narodowych (tradycyjnych 3 maja, 15 sierpnia, 11 listopada oraz nowych powojennych - świętowanych w „polskim Londynie” 1 i 17 września) ważna cezure stanowił rok 1947. Historyk wskazał w tym wypadku na wydarzenia, które wzmocniły rangę uroczystości i ich znaczenie dla procesu cementujacego emigracyjna społeczność wokół niepodległościowych ideałów z przeszłości, tej dalszej z okresu walk o niepodległość i bliższej już wojennej. Wymienił dwa: śmierć i pogrzeb prezydenta Władysława Raczkiewicza oraz złożenie sztandarów PSZ w Instytucie Historycznym im. gen. Sikorskiego (10 VII 1947 r.). W pierwszej sprawie celnie podkreślił, że zmarły prezydent był nie tylko wybitnym politykiem, ale i uosobieniem ciagłości państwa w okresie wojny i po jej zakończeniu. Wokół jego postaci zaś czyniono już zabiegi kreowania legendy „prezydenta - wygnańca”. Z kolei uroczystości złożenia ok. 30 sztandarów w siedzibie Instytutu Historycznego im. gen. Sikorskiego towarzyszyły komentarze, że lokalizacja ma charakter tymczasowy. Docelowo, jak można przypuszczać, każdy myślał o wolnej Polsce ${ }^{51}$. Na znaczenie historyczne i patriotyczne Instytutu Historycznego im. gen. Sikorskiego wskazywali Polacy zamieszkali po wojnie w Londynie. Ową instytucję porównywali do muzeum w Rapperswilu:

Zapewne dla wnuków spod Falaise i Ancony gdy zapomna po latach dat i miejsc bitew, podobnie będzie brzmiała nazwa Instytutu gen. Sikorskiego w Londynie. Już dzisiaj te sale, patrzące oknami na zieleń londyńskich ogrodów są historia i symbolem i gdy chodza po nich przyjezdni z Polski i ze świata - a chodzi po nich wielu - nie szukają tutaj wiadomości, nie notują numerów pułku, czy nazwisk, bo im to wszystko jedno, bo nie chodzi o szczegóły, tylko o wielki dreszcz wzruszenia płynący z każdej ściany, z każdej gablotki ${ }^{52}$.

${ }^{50} 11$ listopada, „Dziennik Polski i Dziennik Żołnierza”, 11 XI 1946, nr 266.

${ }^{51}$ R. Habielski, Życie społeczne i kulturalne emigracji, Warszawa 1999, s. 88-89.

${ }^{52}$ S. Kossowska, Mieszkam w Londynie, Londyn 1994, s. 291-292. 
W 1948 r. w 30. rocznicę odzyskania niepodległości centralne uroczystości odbyły się w „Ognisku Polskim”. W akademii uczestniczyli m.in. prezydent August Zaleski oraz generałowie Władysław Anders i Tadeusz Bór-Komorowski. Okolicznościowe referaty poświęcone gospodarce i kulturze II Rzeczypospolitej wygłosili Mieczysław Sokołowski i Tymon Terlecki.

Pod koniec lat czterdziestych XX w. oraz na początku lat pięćdziesiatych XX w. prezydent August Zaleski, premierzy RP oraz gen. Władysław Anders - którego polska emigracja postrzegała jako męża opatrznościowego emigracji - regularnie zabierali głos przed rocznicami: 3 maja, 15 sierpnia i 11 listopada oraz 1 września, 17 września i 6 sierpnia w rocznicę wymarszu 1 Kompanii Kadrowej. Od 1950 r. środowiska emigracyjne, zwłaszcza związane z 2 Korpusem, dużą rangę nadały rocznicy bitwy pod Monte Cassino. Kwiecień każdego roku był natomiast miesiącem pamięci o zbrodni katyńskiej.

W maju 1949 r. władze RP powołały do życia Radę Narodowa. Tę wcześniej zaplanowaną decyzję należy wiązać z utworzeniem Skarbu Narodowego. Działalność rządu RP, prezydenta, Najwyższej Izby Kontroli, Skarbu Narodowego, Rady Narodowej oraz organizacji i stowarzyszeń oświatowych, kulturalnych i sportowych składały się na instytucję Polskiego Państwa na Obczyźnie. W odezwie rządu RP z 3 V 1949 r. znalazły się odwołania do wydarzeń z przeszłości z uwzględnieniem sytuacji po zakończeniu II wojny światowej, której konsekwencją była m.in. sowiecka strefa wpływów w Europie Środkowo-Wschodniej. „Dzieło 3 Maja zostało zniszczone przez obca przemoc i rodzima zdradę. Ówcześni Targowiczanie spełnili pod koniec XVIII wieku tę rolę, która dziś spełniaja agenci Moskwy, osadzeni przez bagnety sowieckie w Warszawie”. Władze RP poddały krytyce idee komunistyczne odnoszące się nośnego sloganu „demokracji ludowej”, oczywiście w kontekście porównawczym.

Istnieje jeszcze jedna analogia historyczna między czasami konstytucji Trzeciomajowej a chwilą obecną. Wówczas, tak jak dziś, polskie narzędzia moskiewskiej woli nadużywały cynicznie haseł wolności. Różnice są tylko pozorne, koniunkturalne. Wtedy broniono rzekomo „złotej wolności”, jako przyrodzonego przywileju warstwy szlacheckiej, teraz wywiesza się kłamliwy szyld „demokracji ludowej”, która nie ma nic wspólnego z dobrem ludu i jego prawami ${ }^{53}$.

Premier Tadeusz Tomaszewski na posiedzeniu Rady Narodowej 14 XI 1949 r. zwrócił uwagę na sytuację ujarzmionego przez Sowietów kraju. Podkreślił, że przez ostatnie 150 lat, z wyjątkiem dwudziestolecia międzywojennego (1918-1939), Polska była pod zaborami lub kontrolą obcego mocarstwa. To jego zdaniem sprzyjało swobodnej antypolskiej propagandzie, zarówno sowieckiej, jak i niemieckiej, które przy każdej nadarzającej się okazji kreowały negatywny obraz ujarzmionego kraju. Premier podkreślił ogromne

${ }^{53}$ Instytut Polski i Muzeum im. gen. Sikorskiego (dalej: IPMS), A.48.1/R2, Odezwa Rządu Rzeczypospolitej na dzień 3 maja 1949 r., k. 20. 
zaangażowanie i konsekwencję Polaków w obronie wiary i religii. „Jednego tylko Polska nie znała: odstępstwa od Chrystusa i jego Kościoła. To chwała wasza, to klejnot waszej szlachetności, działać z moca, mężnie cierpieć, niezłomnie ufać, dokonywać wielkich rzeczy"54.

W 1950 r. w Londynie gen. Władysław Anders w odezwie do żołnierzy, marynarzy i lotników z okazji 30. rocznicy Bitwy Warszawskiej podkreślił, że Polacy u bram Warszawy zatrzymali pochód sowieckiego imperializmu. Dodał, że ocalili nie tylko swoją Ojczyznę przed zniszczeniem i niewola, ale i Europę Środkową i Zachodnią. „Zwycięstwo jakie odniosły Polskie Siły Zbrojne pod wodzą Józefa Piłsudskiego było wynikiem najwyższego wysiłku całego Kraju, wszystkich jego warstw społecznych. Ale walczyliśmy sami. Kraje zachodnie, których przyszłość była równie zagrożona jak nasza, przyglądały się walce Narodu Polskiego zupełnie biernie. Nie rozumiały niebezpieczeństwa"55. Nie sposób nie zauważyć, iż w dokumencie były dowódca 2 Korpusu wskazał na trzy ważne sprawy. Chociaż nie był wielkim entuzjastą Marszałka, z imienia i nazwiska wymienił Józefa Piłsudskiego jako historycznego wodza. Podkreślił, że sukces stanowił wynik zaangażowania całego społeczeństwa, które w obliczu niebezpieczeństwa chwyciło za broń bez względu na sympatie polityczne. W końcu zasygnalizował wątek zdrady Zachodu, który biernie przyglądał się wydarzeniom nad Wisła. Do tych samych argumentów powrócił w przemówieniu, które wygłosił na forum Stowarzyszenia Polskich Kombatantów 13 VIII 1950 r. w obecności kompletu władz RP na obczyźnie oraz gen. Józefa Hallera, uczestnika Bitwy Warszawskiej. Być może dlatego przywołał w wypowiedzi określenie „Cud nad Wisłą”. Przede wszystkim jednak przypomniał po raz kolejny o roli Marszałka. Dobitnie powiedział, że w 1920 r. „byliśmy samotni, ale byliśmy zjednoczeni”. Celnie również nawiązał do wydarzeń mu współczesnych. Wojny na Półwyspie Koreańskim. „Świat zaczyna rozumieć grożące mu niebezpieczeństwo. Wypadki na Korei stały się sygnałem alarmowym. Zachód demokratyczny, rozbroiwszy się niemal doszczętnie, stanał w obliczu sowieckiej agresji i jej przewagi zbrojnej"56. Analiza sytuacji międzynarodowej, która przeprowadził gen. Anders, zwłaszcza zaś wojna w Korei dały początek idei wykorzystania PSZ w rozwijajacym się konflikcie zbrojnym po stronie Organizacji Narodów Zjednoczonych, w tym USA. Można tu skonstatować, że było to pierwszy akces Polski do NATO. W tej sprawie gen. Władysław Anders i gen. Tadeusz Bór-Komorowski przeprowadzili szczegółowe rozmowy w USA. Oferta nie została jednak przyjęta ${ }^{57}$. Niemniej pomysł powojenny

${ }^{54}$ IPMS, A.48/Z.III/8, Przemówienie premiera T. Tomaszewskiego, wygłoszone na posiedzeniu Rady Narodowej w Londynie w dniu 14 listopada 1949 r., k. 2.

55 Generat broni Wtadystaw Anders..., s. 325.

${ }^{56}$ Ibidem, s. 327.

${ }^{57}$ Przygotowania $i$ przebieg wizyty gen. Tadeusza Bora-Komorowskiego $w$ USA $w 1946 r$. Raport ze zbiorów Instytutu Polskiego i Muzeum Sikorskiego, oprac. T. Wolsza, „Dzieje Najnowsze" 1997, nr 2, s. 153-169; Polityka uchodźstwa polskiego w Wielkiej Brytanii 
rządu RP na obczyźnie, aby nie rozpraszać wojska po całym świecie, okazał się jak najbardziej trafny i na początku lat pięćdziesiątych ciagle aktualny. Żołnierze wprawdzie byli już bez mundurów i broni, ale z uwagi na miejsce pobytu na Wyspach Brytyjskich lub co najdalej we Francji, Włoszech i w Niemczech Zachodnich łatwo można by ich powołać do służby wojskowej pod polskim dowództwem, oczywiście gen. Władysława Andersa.

W latach pięćdziesiątych XX w. nadzieje na zmiany polityczne w Europie Środkowo-Wschodniej zostały rozbudzone przez śmierć sowieckiego dyktatora Józefa Stalina oraz zmiany w kierownictwie państwa sowieckiego, które rozpoczęły się od 1953 r. Jest też zrozumiałe to, że do dyskursu wróciły w szerszym zakresie problemy tożsamości narodowej oraz kultywowania rocznic narodowych. Na łamach „Dziennika Polskiego i Dziennika Żołnierza” pojawił się artykuł, w którym autor podniósł ważny wątek, iż 3 Maja to podwójne święto. „Sejm Ustawodawczy ogłosił 3 maja jako święto państwowe, a Papież Pius XI ustanowił w tym dniu święto Królowej Korony Polskiej. W tym zespoleniu święta narodowego i kościelnego odzwierciedlił raz jeszcze nierozerwalny związek między narodem polskim i Kościołem”. Następnie stwierdził, że w Polsce komunistycznej nie będzie 3 maja flag biało-czerwonych, pochodów i manifestacji. Natomiast w ,oderwanych od Macierzy ziemiach wschodnich, we Lwowie i Wilnie, samo wspomnienie święta narodowego uznane zostało przez najeźdźców za zdradę" 58 . Władze RP nadały również dużą rangę uroczystościom związanym z 55. rocznicą Święta Niepodległości. Uczestniczyli w nich prezydent August Zaleski, premier gen. Roman Odzierzyński, gen. Władysław Anders oraz przedstawiciele Rady Politycznej i Rady Narodowej. Można skonstatować, iż uroczystość przygotowana przez Zjednoczenie Polskie pogodziła, chociaż tylko na jakiś czas, skonfliktowane obozy polityczne skupione wokół prezydenta i Rady Trzech. Główne przemówienie wygłosił gen. Tadeusz Bór-Komorowski. Apelował o zgodę narodową i wspólną walkę na rzecz niepodległości.

Święto Niepodległości [...] służy nam równocześnie przykładem jak wola narodu, który trwa i walczy o swą słuszną sprawę, zdolna jest dokonać czynów na pozór wydajacych się być nieosiagalnymi. Wojna, która stanęła u wrót powstającego państwa, zjednoczyła naród. W obliczu grożącego niebezpieczeństwa wyłoniono jednolite kierownictwo polityczne i wojskowe. Ludzie tej miary jak Piłsudski, Paderewski i Dmowski, pomimo różnych zapatrywań, rozumiejąc konieczność zespolenia i zharmonizowania w tym momencie wszystkich wysiłków, dali wzór całemu narodowi ${ }^{59}$.

w okresie „zimnej wojny”. Podróż gen. Andersa do USA w 1950 r., oprac. A. Zaćmiński, „Dzieje Najnowsze” 1997, nr 2, s. 171-193.

58 Trzeci Maja, „Dziennik Polski i Dziennik Żołnierza”, 3 V 1953, nr 104.

${ }^{59}$ Obchód Święta Niepodległości w Londynie. Gen. Bór-Komorowski o potrzebie jedności narodowej, „Dziennik Polski i Dziennik Żołnierza”, 12 XI 1953, nr 267. 
Postać Józefa Piłsudskiego coraz częściej pojawiała się w dyskursie publicznym odnoszącym się do polskiej drogi do niepodległości. Generał Władysław Anders 11 XI 1954 r. rozwiną sprawę w oparciu o najnowsze publikacje, w tym wspomnienia Wiktora Czernowa, który przywołał szczegóły związane z wykładem Komendanta w paryskim Towarzystwie Geograficznym w 1914 r. Była tam mowa o „zwycięstwie kroczący[m] za zachodu na wschód” i taktyce działania Piłsudskiego. W konkluzji zaś gen. Anders podkreślił, że „taką postacia czołowa w ruchu niepodległościowym w okresie 1914 r. był Józef Piłsudski. Organizował on kadry przyszłego wojska, przygotowywał umysły do wielkiego zrywu wierzac, że przywróci on wolność Polsce. Idea jego była suwerenna, wolna i niezależna Polska..." ${ }^{\circ 0} \mathrm{~W}$ niedalekiej już przyszłości za sprawą działalności oświatowej realizowanej przez władze RP na obczyźnie m.in. na łamach „Wiadomości Ojczystych” do panteonu architektów dzieła niepodległości Polski zostali ponadto włączeni: Roman Dmowski, Ignacy Daszyński, Wincenty Witos i Ignacy Jan Paderewski.

Skala uroczystości niepodległościowych z 1953 r., z uwagi na rozbudzone nadzieje w ,polskim Londynie”, aczkolwiek niespełnione, zdominowała wydarzenia z 1956 r. W przemówieniu majowym, zarejestrowanym przez Radio Wolna Europa, gen. Władysław Anders wskazał, że Polacy przez przeszło półtora stulecia dzielącego nas od Konstytucji 3 maja bez przerwy toczyli walkę o wolność i niepodległość.

Była to walka na dwa fronty - z agresją niemiecką i z zaborczością rosyjska. [...] Rosja [...] w stosunku do Polski jest, tak jak dawniej była: wrogiem naszej wolności i naszego prawa do niepodległego bytu. Rosja carska obdarzyła nas Targowica a Suworow dokonał rzezi Pragi. Rosja bolszewicka obdarzyła nas Komitetem Lubelskim a Bułganin i Rokossowski stali się współtwórcami zniszczenia Warszawy walczącej wówczas bohatersko z okupantem niemieckim ${ }^{61}$.

Uroczystości uświetniła manifestacja Polaków i przedstawicieli innych ujarzmionych narodów z Europy Środkowo-Wschodniej w Londynie przeciwko totalitaryzmowi sowieckiemu, zorganizowana przez Zjednoczenie Polskie. Jak zanotowała Stefania Kossowska, wielotysięczny tłum maszerował w milczeniu i wszystkim wydawało się, że pochód nie ma końca. „Szli w nim generałowie i żołnierze z bojowymi odznaczeniami na cywilnym ubraniu, polscy górnicy z walijskich kopalni, polscy studenci z Oxfordu, [...] szła Armia Krajowa, spadochroniarze, lotnicy, grenadierzy"62. Generał Władysław Anders oceniając londyński pochód, zauważył, iż uczestnicy reprezentowali społeczność licząca w sumie 100 mln ludzi, których w żaden sposób pomijać nie można. Wydarzenie stanowiło nie tylko manifestację $\mathrm{z}$ okazji kolejnej,

\footnotetext{
${ }^{60}$ Generat broni Wtadystaw Anders..., s. 414.

${ }^{61}$ Ibidem, s. 439.

${ }^{62}$ S. Kossowska, op. cit., s. 263.
} 
165. rocznicy uchwalenia Konstytucji 3 maja. Była to również manifestacja katyńska, z czytelnym celem wskazania zbrodniarza Zwiąku Sowieckiego. W końcu był to protest z powodu przyjazdu do Wielkiej Brytanii delegacji sowieckiej z Nikita Chruszczowem i Nikołajem Bułganinem na czele ${ }^{63}$.

Po polskim Październiku i z ogromna nadzieją powodzenia powstania węgierskiego w 1956 r., konkurencyjna wobec władz RP na obczyźnie, Rada Trzech przygotowała specjalna odezwę z okazji 11 listopada. Autorzy protestowali w obliczu sowieckiego barbarzyństwa i krwawej rozprawy z narodem węgierskim. Zabrali jednocześnie głos w sprawie zachowania społeczeństwa w kraju. „Polacy w Kraju dają najwspanialszy przykład głębokiego patriotyzmu i dojrzałej świadomości politycznej”. Studzili emocje społeczeństwa przed zrywem zbrojnym.

Chwila dzisiejsza jest szczególnie niebezpieczna. W Kraju naszym znajdują się liczne wojska sowieckie, a jeszcze liczniejsze otaczają Polskę z zachodu, północy i wschodu. Pomimo fermentu i trudności wewnętrznych Sowiety są nadal dostatecznie silne aby utrzymać swą okupację w Polsce, tym bardziej, że na skuteczna pomoc państw Zachodu, pochłoniętych własnymi trudnościami w tej chwili, liczyć nie możemy ${ }^{64}$.

Dokument podpisali Władysław Anders, Tadeusz Bór-Komorowski i Edward Raczyński, elita polskiej emigracji politycznej. Redakcja dziennika pomieściła jeszcze artykuł pt. Jedenasty Listopada. Pojawiła się w nim pochwała społeczeństwa w kraju, które potrafi się oprzeć próbom zatrucia jego duszy i osłabienia zbiorowej woli. „Polska cała, jak długa i szeroka wsłuchuje się z zapartym oddechem w odgłosy dochodzące z Węgier. Tragiczna walka bratniego narodu, prowadzona bez pomocy wolnego świata, ma wstrzasająca wymowę. Nasze własne doświadczenia historyczne sprawiają że Polska najlepiej rozumie i odczuwa ogrom węgierskiego dramatu”. Warto zauważyć, iż autor podkreślił w tekście, że warunki, w których nasz naród toczył walkę o niepodległość i w końcu ją wygrał, były pozornie beznadziejne. Niemniej pomimo klęsk nie skapitulował i nigdy nie stracił nadziei. W 1918 r. sukces wynikał z własnej siły narodu i koniunktury międzynarodowej. Przechodząc do sytuacji z połowy lat pięćdziesiątych, dostrzegł wspaniała postawę młodzieży w Kraju, odporność polskiego robotnika na propagandę ze Związku Sowieckiego, przywiązanie chłopa do ziemi ojczystej oraz ofiarna prace inteligencji. To zdaniem autora tekstu fundament, na którym można oprzeć wielki optymizm. Wyrokował, że Polska przeżyje jeszcze znowu chwilę odzyskania niepodległości. „W roku 1918 było to dnia 11 listopada. Nie znamy jeszcze dokładnie przyszłej radosnej daty. Ale wiemy na pewno, że dzień ten nadejdzie...” ${ }^{65}$ Polacy na emigracji i w kraju na ten dzień czekali jeszcze 33 lata.

\footnotetext{
${ }^{63}$ T. Wolsza, „Katyń to już na zawsze katy i katowani”. W „polskim Londynie” o sowieckiej zbrodni w Katyniu (1940-1956), Warszawa 2008, s. 132-135.

${ }^{64}$ Rada Trzech na 11 listopada, „Dziennik Polski i Dziennik Żołnierza”, 10 XI 1956, nr 269.

${ }^{65}$ Jedenasty listopada, „Dziennik Polski i Dziennik Żołnierza”, 10 XI 1956, nr 269.
} 


\section{Streszczenie}

Można bez cienia wątpliwości skonstatować, że Druga Wielka Emigracja była depozytariuszem II Rzeczypospolitej w kontekście kształtowania i podtrzymywania tożsamości narodowej Polaków, których wojenne losy rzuciły m.in. do Francji, Wielkiej Brytanii, USA oraz do kilku innych krajów. Władze RP przykładały dużą wagę do sprawy kształtowania tożsamości narodowej przez kultywowanie rocznic narodowych uchwalenia Konstytucji 3 maja, odzyskania niepodległości w 1918 r. oraz historycznego zwycięstwa Wojska Polskiego nad bolszewikami w Bitwie Warszawskiej 15 VIII 1920 r. Rangę święta najważniejszego, w latach wojny, zyskała w kręgach emigracyjnych rocznica konstytucji. Władze RP minimalizowały natomiast znaczenie postaci Józefa Piłsudskiego. Po wojnie władze RP powoli przywróciły należne znaczenie Świętu Niepodległości. Z kolei święto Konstytucji zyskało rangę „Daru 3-go Maja”, początkowo pod patronatem prezydenta Władysława Raczkiewicza, zaś później Augusta Zaleskiego. Celem akcji było dofinansowanie oświaty dla dzieci polskich na emigracji.

\section{National Independence Day of 11 November and Other National Holidays in Propaganda and Educational Activities of the Polish Government-in-Exile (the 1940s and 1950s)}

It can be concluded without a doubt that the Second Great Emigration was a depositary of the Second Polish Republic in terms of shaping and maintaining the national identity of the Poles cast by wartime fate to France, Great Britain, USA and several other countries. The Polish authorities attached great importance to the shaping of national identity by cultivating national anniversaries of the 3 May Constitution, regaining independence in 1918, and the historical victory of the Polish Army over the Bolsheviks in the Battle of Warsaw on 15 August 1920. The most important among the holidays became the anniversary of the adoption of the 3 May Constitution. On the other hand, the Polish authorities minimized the significance of Józef Piłsudski. After the war, however, the state authorities slowly restored the due importance to the Independence Day, while the Constitution Day gained the rank of the "Gift of the 3rd May", initially under the patronage of President Władysław Raczkiewicz, and then of August Zaleski. The aim of the campaign was to subsidize the education of Polish children in exile.

\section{Bibliografia}

Dobroński A., Obchody rocznic Konstytucji 3 Maja w „polskim Londynie”, w: Między historia a prawem, red. P. Leszczyński, R. Nir, M. Szczerbiński, Gorzów Wlkp. 2007.

Dymarski M., Polskie obozy odosobnienia we Francji i $w$ Wielkiej Brytanii w latach 1939-1942, „Dzieje Najnowsze” 1997, nr 3.

Dymarski M., Stosunki wewnętrzne wśród polskiego wychodźstwa politycznego i wojskowego we Francji $i$ w Wielkiej Brytanii 1939-1945, Wrocław 1999.

Habielski R., Życie społeczne i kulturalne emigracji, Warszawa 1999.

Kaczmarski K., O Wielka Polskę na wojennym wychodźstwie. Stronnictwo Narodowe wobec rzadu gen. Wtadystawa Sikorskiego (1939-1943), Rzeszów 2013.

Korol-Chudy A., „Czy chcecie, by was nadal wodzono za nos”? Propaganda niemiecka wobec żotnierzy 2. Korpusu Polskiego we Wtoszech. Cele - środki-motywy, w: Za nasza i wasza wolność. Bitwa o Monte Cassino z perspektywy polskiej i wtoskiej, red. C. Salmeri, Katowice 2017. 
Król E.C., Polska i Polacy w propagandzie narodowego socjalizmu w Niemczech 1919-1945, Warszawa 2006.

Mazowiecki W., Pierwsze starcie. Wydarzenia 3 maja 1946, Warszawa 1998.

Piotrowski J., „Skandaliczna” audycja w polskojęzycznej rozgłośni BBC 12 maja 1940 r., „Niepodległość" 2007, t. LVII.

Podhorodecki P., Turza A., Pierwszy projekt ustanowienia dnia 11 listopada Narodowym Świętem Niepodlegtości, „Przegląd Historyczno-Wojskowy” 2018, nr 1-2.

Polityka uchodźstwa polskiego w Wielkiej Brytanii w okresie „zimnej wojny”. Podróż gen. Andersa do USA w 1950 r., oprac. A. Zaćmiński, „Dzieje Najnowsze” 1997, nr 2.

Pragier A., Puszka Pandory, Londyn 1969.

Przygotowania $i$ przebieg wizyty gen. Tadeusza Bora-Komorowskiego $w$ USA $w 1946$ r. Raport ze zbiorów Instytutu Polskiego i Muzeum Sikorskiego, oprac. T. Wolsza, „Dzieje Najnowsze" 1997, nr 2.

Tchórzewska-Hautt M., Obchody dnia niepodlegtości w Polsce w latach 1920-1988, w: Idea niepodległości i suwerenności narodowej $w$ działalności Polaków w kraju i na obczyźnie (1918-1998), red. M. Szczerbiński, Gorzów Wlkp. 2000.

Wachowska B., Od 11 listopada do 11 listopada czyli spory o symboliczne święto niepodległości Polski, „Acta Universitatis Lodziensis. Folia Historica” 1995, nr 54.

Wojewódzki I., Kazimierz Sosnkowski podczas II wojny światowej. Ksiażę niezłomny czy Hamlet $w$ mundurze?, Warszawa 2009.

Wolsza T., „Katyń to już na zawsze katy i katowani”. W „polskim Londynie” o sowieckiej zbrodni w Katyniu (1940-1956), Warszawa 2008.

Wolsza T., Rzqd bez wtadzy? Uwagi na temat dziatalności rzqdu RP na obczyźnie w latach 1939-1989. Przeglad i postulaty badawcze, „Dzieje Najnowsze” 2010, nr 4.

Wolsza T., „To co widziatem przekracza swa groza najśmielsze fantazje”. Wojenne i powojenne losy Polaków wizytujacych Katyń w 1943 roku, Warszawa 2015.

Wolsza T., Wokót milenium 1966 r., „Wiadomości Historyczne” 2002, nr 4.

Zuziak J., Obozy izolacyjne Rothesay i Tignabruaich. Z historii Polskich Sit Zbrojnych na Zachodzie, „Mars” 1995, nr 3.

Biog r a m: Tadeusz Wolsza - prof. dr hab.; pracownik Instytutu Historii PAN w Warszawie i Instytutu Nauk Politycznych Uniwersytetu Kazimierza Wielkiego w Bydgoszczy. Prowadzi badania naukowe na temat dziejów polskiej powojennej emigracji w Wielkiej Brytanii, więziennictwa stalinowskiego w Polsce oraz historii sportu. E-mail: mwolsza@wp.pl. 